\title{
PENGARUH PERBANDINGAN RUMPUT LAUT SEGAR Ulva lactuca DENGAN LARUTAN ASAM CUKA TERHADAP KARAKTERISTIK BIOPLASTIK ALGINAT
}

\author{
I Ketut Pramananta, Bambang Admadi Harsojuwono*, Amna Hartiati \\ PS Teknologi Industri Pertanian, Fakultas Teknologi Pertanian, Universitas Udayana, Kampus Bukit \\ Jimbaran, Badung, Kode pos : 80361; Telp/Fax : (0361) 701801.
}

Diterima 09 April 2019 / Disetujui 12 Agustus 2019

\begin{abstract}
This study aims to determine the effect of the comparison of Ulva lactuca and vinegar acid on the characteristics of bioplastic alginate and determine the comparison of seaweed with the right vinegar solution so as to produce the best bioplastic alginate characteristics. This study uses a completely randomized design with a comparison treatment of Ulva lactuca seaweed with dissolved sam vinegar. The experiment was carried out with a ratio of 0.5: 2.5, 1.0: 2.0, 1.5: 1.5, 2.0: 1.0, 2.5: 0.5 with the treatment repeated 4 times so that 20 experimental units were obtained. Variables observed were tensile strength, percent extension, Young Modulus, thickness, biodegradation. The results of this study showed that vinegar acid solution had a significant effect on tensile strength, percent extension, Young Modulus, period of biodegradation and thickness of plastic. Comparison of seaweed and vinegar (2.5: 0.5). produce the best bioplastic alginate with characteristics: the percentage of biodegradation loss value 0,49\% - 0,51\%, increasing thickness period of 218,25 $\mu \mathrm{m}$, tensile strength 1,86 MPa, Young Modulus 14,55 MPa and bioplastic extension 34,91\%.
\end{abstract}

Keyword: bioplastic, Alginate, Ulva lactuca and vinegar acid solution

*Korespondensi Penulis:

Email : bambang.admadi@unud.ac.id 


\section{PENDAHULUAN}

Plastik pertama kali ditemukan pada tahun 1907, Semenjak itu penggunaan plastik dan barang-barang berbahan dasar plastik semakin meningkat. Penyebab peningkatan penggunaan plastik ini adalah perkembangan teknologi, industri dan juga jumlah populasi penduduk. Di Indonesia, kebutuhan plastik terus meningkat hingga mengalami kenaikan rata-rata 200 ton pertahun. Pada tahun 2002, terdapat 1,9 juta ton, dan ditahun 2011, sudah meningkat menjadi 2,6 juta ton. Akibat dari peningkatan penggunaan plastik ini adalah bertambah pula sampah plastik. Berdasarkan asumsi Kementerian Lingkungan Hidup (KLH), setiap hari penduduk Indonesia menghasilkan $0,8 \mathrm{~kg}$ sampah per orang atau secara total sebanyak 189 ribu ton sampah/hari. Dari jumlah tersebut $15 \%$ berupa sampah plastik atau sejumlah 28,4 ribu ton sampah plastik/hari (Pahlevi, 2012).

Sampah plastik menjadi masalah lingkungan berskala global. Plastik banyak dipakai dalam kehidupan sehari-hari. Namun selama ini plastik yang sering kita gunakan adalah polimer sintetik yang terbuat dari minyak bumi yang sulit untuk terurai di alam. Bahan kemasan yang berasal dari polimer petrokimia yakni plastik sangat populer digunakan karena memiliki beberapa keunggulan, yaitu fleksibel (mengikuti bentuk produk), transparan, tidak mudah pecah, dapat dikombinasikan dengan kemasan lain, dan tidak korosif. Akibatnya semakin banyak yang menggunakan plastik, akan semakin meningkat pula pencemaran lingkungan seperti pencemaran tanah. Oleh karena perlu mencari solusi untuk mengatasi masalah lingkungan ini, salah satunya yaitu mengembangkan bahan plastik biodegradable (bioplastik). Bioplastik ini dapat diuraikan kembali oleh mikroorganisme secara alami menjadi senyawa yang ramah lingkungan. Pengembangan bahan plastik biodegradable menggunakan bahan alam yang terbaharui (renewable resources) sangat diharapkan (Hardaning, 2001; Averous, 2004).

Indonesia merupakan negara kepulauan yang memiliki kurang lebih $70 \%$ laut yang kaya akan berbagai jenis sumber hayati. Salah satu rumput laut yang banyak terdapat di Indonesia dan belum dimanfaatkan secara optimal adalah Ulva lactuca. Komposisi kimia polisakarida pada Ulva lactuca berpontensi sebagai bahan baku industri pangan maupun non pangan khususnya bioplastik. Alginat merupakan polisakarida alami yang bersifat kental dan larut dalam air.Kondisi sangat potensial untuk dimanfaatkan sebagai bioplastik. Polisakarida pada Ulva lactuca memiliki keunggulan yaitu dapat meningkatkan viskositas. Karena itu pada penelitian ini akan dilakukan pembuatan bioplastik menggunakan rumput laut Ulva lactuca. Ulva lactuca banyak terdapat di pantai berdasar batu karang mati terutama pada rataan terumbu karang seperti di pantai serangan secara liar. Komposisi kimia polisakarida pada Ulva lactuca berpontesi sebagai bahan baku industri pangan maupun non pangan khususnya bioplastik. susunan tubuhnya foliaceaus (helaian) atau parenkimatis (lembaran tipis), yang pembelahan sel vegetative terjadi lebih dari satu bidang. Polimer hasil dari Ulva lactuca mempunyai sifat termoplastik sehingga mempunyai potensi untuk di bentuk atau dicetak menjadi film kemasan. Keunggulan polimer jenis ini adalah tersedia sepanjang tahun (renewable) dan mudah hancur secara alami (biodegradable). berdasarkan hal tersebut, polimer jenis ini dapat digunakan sebagai bahan bioplastik yaitu plastic yang dapat diuraikan kembali oleh mikroorganisme secara alami menjadi senyawa yang ramah lingkungan. asam cuka terhadap karakteristik bioplastik alginat, sehingga perlu dilakukan penelitian lebih lanjut dan penelitian lain yang sudah ada sebagai pendukung. 
Penelitian ini bertujuan untuk mengetahui pengaruh perbandingan rumput laut Ulva lactuca dengan asam cuka terhadap karakteristik bioplastik alginat.

\section{METODE PENELITIAN}

\section{Tempat dan Waktu Penelitian}

Penelitian ini dilaksanakan di Laboratorium Bioindustri dan Laboratorium Analisis Pangan Fakultas Teknologi Pertanian Universitas Udayana, Pada bulan Mei 2018 - Juli 2018.

\section{Alat dan Bahan Penelitian}

Alat yang digunakan adalah Baskom, kain saring, blender, Water bath, Oven, cetakan Teflon (Maxim), Gelas beaker (Herma), Erlenmeyer (Herma), Timbangan analitik (ohaus pioneer), Pipet tetes, dan Termometer, Hot plate strirer, Labu Takar, corong, spatula, kertas label, dan gunting.

Bahan yang digunakan adalah terdiri dari bahan baku dan bahan kimia. Bahan baku yaitu: Rumput laut Ulva lactuca yang di dapatkan dari Pantai Serangan dengan umur panen \pm 15 hari. Bahan kimia yaitu: Asam asetat $\left(\mathrm{CH}_{3} \mathrm{COOH}\right) 1 \%$, Gliserol $\left(\mathrm{C}_{3} \mathrm{H}_{8} \mathrm{O}_{3}\right)$, dan Aquades.

\section{Metode}

Rancangan percobaan pada penelitian ini yaitu Rancangan Acak Lengkap (RAL) dengan perlakuan perbandingan rumput laut hijau Ulva lactuca dengan larutan asam cuka, sebagai berikut:

P1 : $(0.5: 2.5)$

$\mathrm{P} 2 \quad:(1.0: 2.0)$

P3 $\quad:(1.5: 1.5)$

P4 : $(2.0: 1.0)$

P5 $\quad:(2.5: 0.5)$

Perlakuan diulang 4 kali sehingga diperoleh 20 unit percobaan data yang dianalisis keragamannya dan bila berpengaruh nyata dilanjutkan dengan pengujian dengan BNT.

\section{Preparasi Rumput Laut Ulva lactuca.}

Mencuci dan penyortiran rumput laut kemudian, ditiriskan selama 10 menit, Menimbang rumput laut dan larutan asam cuka $1 \%$ sesuai perlakuan, campur rumput laut dan larutan asam cuka 1\% kemudian diblender sampai halus menjadi bubur/pulp, setelah itu dituangkan ke dalam gelas beaker $200 \mathrm{ml}$ kemudian dipanaskan dengan suhu $70^{\circ} \mathrm{C}$ selama 10 menit, lalu disaring menggunakan kain saring sehingga memperoleh filtrate kemudian menimbang filtrate sebanyak 199 gr lalu ditambahkan $1 \mathrm{gr}$ gliserol dan dipanaskan dengan suhu $70^{\circ} \mathrm{C}$ selama 10 menit, kemudian gel dituangkan ke dalam cetakan teplon berdiameter $20 \mathrm{~cm}$, lalu sampel tersebut dimasukan ke dalam oven dengan suhu $80^{\circ} \mathrm{C}$ selama 4 jam, setelah itu didiamkan selama 24 jam dalam suhu ruangan. Selanjutnya lembaran bioplastic dilepas dari teplon sehingga diperoleh bioplastic yang siap diuji

\section{Variabel yang Diamati}

Variabel yang diamati terhadap bioplastik alginat dari rumput laut Ulva lactuca meliputi biodegradasi, ketebalan bioplastik, persen pemanjangan, Modulus young dan kekuatan tarik.

\section{HASIL DAN PEMBAHASAN}

\section{Biodegradasi}

Berdasarkan hasil keragaman menunjukan bahwa perbandingan rumput laut dengan larutan asam cuka berpengaruh sangat nyata terhadap kemampuan biodegradasi atau persen kehilangan massa dari bioplastic. Nilai kehilangan massa (biodegradasi) selama 10 hari berkisar antara $0.49 \%$ - 0.51\%. Kemampuan Biodegradasi bioplastik dari rumput laut Ulva lactuca dapat dilihat pada Tabel 1. Juga menunjukkan kemampuan biodegradasi yang rendah terjadi pada $(2,0: 1,0)$ dan $(2,5: 0,5)$ yang beda nyata dengan $(1,5: 1,5)$ dan kemampuan 
biodegradasi yang tinggi terjadi pada $(0,5$ : 2,5) dan $(1,0: 2,0)$.

Tabel 1. Nilai rata-rata kemampuan

\begin{tabular}{ll}
\multicolumn{2}{c}{ biodegradasi bioplastik (\%) } \\
\hline $\begin{array}{l}\text { Perlakuan } \\
\text { Rumput laut } \\
\text { Asam cuka }\end{array}$ & $\begin{array}{l}\text { Rata-rata } \\
\text { Biodegradasi }(\%)\end{array}$ \\
\hline $0,5: 2,5$ & $0.49 \mathrm{~b}$ \\
$1,0: 2,0$ & $0.38 \mathrm{~b}$ \\
$1,5: 1,5$ & $0.48 \mathrm{ab}$ \\
$2,0: 1,0$ & $0.52 \mathrm{a}$ \\
$2,5: 0,5$ & $0.51 \mathrm{a}$ \\
\hline
\end{tabular}

Keterangan : huruf yang berbeda di belakang rata-rata menunjukan perbedaan nyata pada taraf kesalahan 5\%

Berdasarkan data dari Tabel 1 dapat dilihat rata-rata kemampuan biodegradasi yang tinggi terdapat pada komposit dengan perlakuan $(2,5: 0,5)$ dan $(2,0: 1,0)$ yang tidak beda nyata dengan $(1,5: 1,5)$. Perlakuan biodegradasi terendah terdapat pada komposit dengan perlakuan (0.5 : 2.5). Berdasarkan hasil tersebut dapat dilihat perlakuan rumput laut yang semakin tinggi menyebabkan partikel plastik banyak mengalami perubahan fisik kimia menjadikan plastik semakin homogen dan strukturnya rapat, dengan karakteristik tersebut tentunya menyebabkan mikroorganisme sulit menguraikan partikelpartikel penyusun plastik (Gontard et al, 1993).

\section{Uji Ketebalan}

Berdasarkan hasil analisis keragaman perbandingan rumput laut dengan larutan asam cuka berpengaruh sangat nyata terhadap ketebalan bioplastik. Nilai ketebalan bioplastik selulosa berbahan dasar rumput laut Ulva lactuca dapat dilihat pada Tabel 2. Semakin tinggi perlakuan rumput laut menyebabkan ketebalan dari bioplastik semakin meningkat.

Tabel 2. Nilai rata-rata ketebalan bioplastik $(\mu \mathrm{m})$

\begin{tabular}{ll}
\hline $\begin{array}{l}\text { Perlakuan } \\
\text { Rumput laut : } \\
\text { Asam cuka }\end{array}$ & $\begin{array}{l}\text { Rata-rata } \\
\text { Ketebalan }(\mu \mathrm{m})\end{array}$ \\
\hline $0,5: 2,5$ & $108.75 \mathrm{c}$ \\
$1,0: 2,0$ & $147.75 \mathrm{~b}$ \\
$1,5: 1,5$ & $178.75 \mathrm{ab}$ \\
$2,0: 1,0$ & $201.25 \mathrm{a}$ \\
$2,5: 0,5$ & $218.25 \mathrm{a}$ \\
\hline $\begin{array}{l}\text { Keterangan: huruf yang berbeda di belakang rata-rata } \\
\text { menunjukkan perbedaan nyata pada taraf } \\
\text { kesalahan 5\% }\end{array}$
\end{tabular}

Berdasarkan data dari Table 2 dapat dilihat ketebalan terdapat pada bioplastik dengan perlakuan $(2,5: 0,5)$ dan $(2,0: 1,0)$ adalah yang paling tebal yang tidak beda nyata dengan $(1,5: 1,5)$. Perlakuan terendah terdapat pada perlakuan $(0,5: 2,5)$. Berdasarkan hasil tersebut dapat dilihat bahwa perlakuan berpengaruh terhadap ketebalan dari bioplastik berbahan dasar ekstrak kasar Ulva lactuca. Semakin rendah perlakuan Rumput laut maka ekstrak yang dihasilkan semakin tipis (Setiani et al., 2013).

\section{Uji Kekuatan Tarik (Tensile strength)}

Berdasarkan hasil analisis keragaman perbandingan rumput laut dengan larutan asam cuka berpengaruh sangat nyata terhadap kekuatan Tarik. Nilai kekuatan tarik berkisar antara $0.55 \mathrm{MPa}-1.86 \mathrm{MPa}$ seperti terlihat pada Tabel 3.

Tabel 3. Nilai rata-rata kekuatan Tarik bioplastik (MPa)

\begin{tabular}{ll}
\hline $\begin{array}{l}\text { Perlakuan } \\
\text { Rumput laut : } \\
\text { Asam cuka }\end{array}$ & $\begin{array}{l}\text { Rata-rata } \\
\text { Kekuatan tarik } \\
(\mathrm{mpa})\end{array}$ \\
\hline $0.5: 2.5$ & $0,55 \mathrm{e}$ \\
$1.0: 2.0$ & $0.86 \mathrm{~d}$ \\
$1.5: 1.5$ & $1.16 \mathrm{c}$ \\
$2.0: 1.0$ & $1.35 \mathrm{~b}$ \\
$2.5: 0.5$ & $1.86 \mathrm{a}$ \\
\hline
\end{tabular}

Keterangan: huruf yang berbeda di belakang rata-rata menunjukan perbedaan nyata pada taraf kesalahan $5 \%$ 
Pada.Tabel 3. Terlihat bahwa nilai kekuatan tarik yang tinggi terdapat pada perbandingan rumput laut dengan larutan asam cuka $(2,5: 0,5)$ dan $(2,0: 1,0)$. Kekuatan tarik terendah terdapat pada perbandingan $(0,5: 2,5)$. Semakin rendah perlakuan rumput laut maka kekuatan tarik akan semakin rendah. Semakin banyak Rumput laut yang ditambahkan maka nilai kuat tariknya cenderung meningkat, dikarenakan Rumput laut dapat membentuk ikatan hidrogen antar rantai sehingga bioplastik menjadi lebih rapat, sehingga plastik semakin kuat dan sulit di putus (Setiani et al., 2013).

\section{Uji Elastisitas (Modulus young)}

Berdasarkan analisis keragaman perbandingan rumput laut dengan asam cuka berpengaruh sangat nyata terahadap (Modulus young) bioplastik komposit. Nilai Modulus Young bioplastik rumput laut dan asam cuka berkisar antara 1,59-14,55 $\mathrm{MPa}$, seperti terlihat pada Tabel 4.

Tabel 4. Nilai rata-rata elastisitas (Modulus young) (MPa) bioplastik.

\begin{tabular}{ll}
\hline $\begin{array}{l}\text { Perlakuan } \\
\text { Rumput laut : } \\
\text { Asam cuka }\end{array}$ & $\begin{array}{l}\text { Rata-rata } \\
\text { elastisitas }(\mathrm{MPa})\end{array}$ \\
\hline $0,5: 2,5$ & $1,59 \mathrm{c}$ \\
$1,0: 2,0$ & $4,31 \mathrm{~b}$ \\
$1,5: 1,5$ & $7,68 \mathrm{ab}$ \\
$2,0: 1,0$ & $9,58 \mathrm{a}$ \\
$2,5: 0,5$ & $14,55 \mathrm{a}$ \\
\hline
\end{tabular}

Keterangan : huruf yang berbeda di belakang rata-rata menunjukan perbedaan nyata pada taraf kesalahan 5\% Elastisitas (Modulus young) merupakan ukuran kekakuan suatu bahan.

Elastisitas merupakan perbandingan dari kuat tarik dengan elongasi. Pada Tabel 5 terlihat bahwa nilai Modulus Young yang tinggi terdapat pada perlakuan $(2,5: 0,5)$ dan $(2,0: 1,0)$, sedangkan nilai Modulus Young terendah terdapat pada perlakuan perbandingan $(0,5: 2,5)$ dam $(1,0: 2,0)$. Berdasarkan data Tabel 5 nilai elastisitas bioplastik dipengaruhi oleh perlakuan rumput laut (Ulva lactuca) dan asam cuka.Nilai elastisitas berbanding lurus dengan nilai kuat tarik sedangkan berbanding terbalik dengan elongasi (Darni dan Utami, 2010). Semakin banyak perbandingan rumput laut yang digunakan dan perlakuan asam cuka yang semakin rendah maka nilai elastisitas semakin meningkat. Hal ini sependapat dengan Setiani et al., (2013) dan Darni dan Utami (2010).

\section{Uji perpanjangan}

Berdasarkan analisis keragaman perbandingan rumput laut dengan asam cuka berpengaruh sangat nyata Nilai perpanjangan saat putus rumput laut dengan asam cuka berkisar antara $12,68 \%$ - 34,91\% seperti terlihat pada Tabel 5 .

Tabel 5. Nilai rata-rata perpanjangan bioplastik (\%)

\begin{tabular}{ll}
\hline $\begin{array}{l}\text { Perlakuan } \\
\text { Rumput laut } \\
\text { Asam cuka }\end{array}$ & $\begin{array}{l}\text { Rata-rata } \\
\text { perpanjangan }(\%)\end{array}$ \\
\hline $0.5: 2.5$ & $34.91 \mathrm{a}$ \\
$1.0: 2.0$ & $20.08 \mathrm{~b}$ \\
$1.5: 1.5$ & $15.22 \mathrm{c}$ \\
$2.0: 1.0$ & $14.19 \mathrm{c}$ \\
$2.5: 0.5$ & $12.68 \mathrm{~d}$ \\
\hline
\end{tabular}

Keterangan : huruf yang berbeda di belakang rata-rata menunjukkan perbedaan nyata pada taraf kesalahan 5\%

Pada Tabel 5 terlihat bahwa persen perpanjangan saat putus (Elongation at break) yang tinggi terdapat pada campuran bahan rumput laut dan larutan asam cuka $(0,5$ $: 2,5)$ dan $(1,0: 2,0)$ yang beda nyata dengan $(1,5: 1,5)$. Persentase yang terendah terdapat pada campuran bahan rumput laut dan larutan asam cuka $(2,5: 0,5)$. Semakin besar konsentrasi Asam cuka, maka persentase elongation semakin menurun (Setiani et al., 2013).

KESIMPULAN DAN SARAN 


\section{Kesimpulan}

Berdasarkan hasil penelitian yang dilakukan dapat disimpulkan bahwa pengaruh perbandingan rumput laut dengan asam cuka berpengaruh nyata terhadap karakteristik bioplastik pada analisis Biodegradasi, Ketebalan, Modulus Young, Kuat tarik dan Perpanjangan. Perbandingan (2.5: 0.5) menghasilkan bioplastic alginat terbaik dengan karakteristik : persentase nilai kehilangan biodegradasi $0,51 \%$, peningkatan masa ketebalan sebanyak 218,25 $\mu \mathrm{m}$, kekuatan Tarik 1,86 MPa, Modulus young $14,55 \mathrm{MPa}$ dan perpanjangan bioplastik $34,91 \%$.

\section{Saran}

Saran dari hasil penelitian ini yaitu pengembangan untuk menjernihkan warna bioplastik yang dihasilkan.

\section{DAFTAR PUSTAKA}

Abadi, R. dan N. Nuryati. 2007. Bahanbahan Penolong Kita. Pakar Raya. Bandung

Anggadireja J. , Azatniko W., Sujatmiko dan Noor I. 1993 Teknologi Produk Perikanan dalam Industri Farmasi. Dalam Stadium General Teknologi dan Alternatif Produk Perikanan dalam Industri Farmasi.

Averous, 2004 Biodegradable multiphase systems based on plasticized starch: A review, Journal of Macromolecular Science, 12, 123-130.

Bahmid, A 2014 Pengaruh Ukuran Serat Selulosa Asetat dan Penambahan Dietilen Glikol (Deg) Terhadap Sifat Fisik dan Mekanik Bioplastik.Teknologi Industri Pertanian, Fakultas Teknologi Pertanian, Institut Pertanian Bogor Kampus IPB Darmaga 16002,
Indonesia.

Ban, W. 2006. Influence of natural biomaterials on the elastic properties of starch-derived films: An optimization study, Journal of Applied Polymer Science, 15, 30-38.

Darni, Y., A Chici., D. S. Ismiyati. 2008. Sintesa Bioplastik dari Pati Pisang dan Gelatin dengan Plasticizer Gliserol. Prosiding Seminar Nasional Sains dan Teknologi-II 2008 Lampung: Universitas Lampung.

Darni, Y., A Chici., D. S. Ismiyati. 2008. Sintesa Bioplastik dari Pati Pisang dan Gelatin dengan Plasticizer Gliserol. Prosiding Seminar Nasional Sains dan Teknologi-II 2008 Lampung: Universitas Lampung.

Gallaher, D. 2000. Dietary Fiber and Its Physiological Effect In Essential Of Functional Food. Schmidl, M.K, T.P. (Eds). An Aspen Publication. Maryland. Page:273-292

Griffin, J.G.L. 1994. Chemistry and Technology of Biodegradable Polymers. Chapters 1-3 Blackie Academic and Profesional, London.

Gontard, N.S., Guilbert, \& J.L., Cuq. 1993. Water and Glycerol as Plasticizer Effect Mechanical and Water Vapor Barrier Properties of an Edible Wheat Gluten Film. J.Food Sci., Vol. 58(1) : 206-211.

Hardaning, P. 2001. PengembanganBahan Plastik Biodegradabel Berbahan Baku Pati Tropis, Badan Pengkajian dan Penerapan Teknologi-BPPT. Jakarta.

Kadi, A. 2005.Kesesuaian Perairan Teluk Klabat Pulau Bangka Untuk Usaha Budidaya Rumput Laut . Jurnal Oseana Vol. 30: Hal. 4-7.

Kramer, H. dan J. Scharnagl. 1994. 
Pengetahuan Bahan Untuk Industri. Penebar Swadaya, Jakarta.

Pahlevi, M.R., 2012, Sampah Plastik (file:///I:/Artikel\%20plastic\%20to\%20 oil/twit-sampah-plastik.html)

Raynasari B. 2012. Pengaruh Suhu Penyimpanan Terhadap Sifat Fisik dan Mekanik Kemasan Plastik Retail. [Skripsi]. Bogor: Institut Pertanian Bogor.

Rohman, M.A, 2016.Pengaruh Penambahan Glutaraldehida Terhadap Karakteristik Filmbioplastik Kitosan Terplastis Carboxy Methyl Cellulose $(C M C)$.[Skripsi].Surabaya: Universitas Airlangga.

Santi R. A. Komposisi Kimia dan Profil Polisakarida Rumput Laut Hijau. Akuatika Vol.III No.2, (105-114) ISSN 0853-2523.

Santosa, G.W. 2003.Budidaya Rumput Laut. Program Community College Industri Kelautan dan Perikanan. Universitas Diponegoro. Semarang.

Setiani, W., T. Sudiarti dan L. Rahmindar. 2013. Preparasi Dan Karakterisasi Edible Film Dari

Poliblend Pati Sukun-Kitosan. Jurnal Kimia Valensi Vol. 3 No. 2, November 2013 (100-109) ISSN : 1978 - 8193. Jurusan Kimia Fakultas Sains dan Teknologi UIN Sunan. Gunung Djati Bandung

Suharmi, dan S. Achmad. 2009. Kajian Pemanfaatan Sumber Daya Rumput Laut Dari Aspek Industri Dan Kesehatan. Jurusan Magister Manajemen Sumber Daya Pantai Universitas Diponegoro.

Soegiarto, A. Sulistijo. W, S, Atmaja dan H, Mubarak. 1978. Rumput Laut, Manfaat, Potensi, dan Usaha Budidayanya.
LON-LIPI. Jakarta. 49 Hlm.

Tjitrosoepomo, G., 2011.Taksonomi Tumbuhan : Schizophyta, Thallophyta, Bryophyta, Pterydophyta.Gadjah Mada University Press, Yogyakarta.

Vilpoux, O. and Averous. 2006. StarchBased Plastic. Latin American Starchy Tubers.

Whyman, K. Seri Life Skill Lingkungan hidup plastik dan lingkungan. Pakar Raya Pustaka, Bandung.

Winarno, F.G. 1991. Kimia Pangan Dan Gizi. PT. Gramedia Pusaka Utama, Jakarta.

Winarno, F.G. 1994. Sterilisasi Komersial Produk Pangan. PT. Gramedia Pusaka Utama, Jakarta.

Yuniarti, L.I, G.S. Hutomo dan A. Rahim. 2014. Sintesis Dan Karakterisasi Bioplastik Berbasis Pati Sagu (Metroxylon $s p$ ). e-Journal Agrotekbis 2(1) : 38-46. ISSN: 2338-3011 